\title{
Analysis of Geochemical Samples by Microwave Plasma-AES
}

\author{
Balaram Vysettia ${ }^{a}$, Dharmendra Vummiti ${ }^{\mathrm{b}, \mathrm{e}}$, Parijat Roy ${ }^{\mathrm{c}}$, Craig Taylor ${ }^{\mathrm{d}}$, C.T. Kamala ${ }^{\mathrm{a}}$, M. Satyanarayanan ${ }^{\mathrm{a}}$, \\ Prasenjit Kar $^{\mathrm{b}}$, K.S.V. Subramanyam ${ }^{\mathrm{a}}$, Arun Kumar Raju ${ }^{\mathrm{b}}$, and Krishnaiah Abburie \\ ${ }^{a}$ CSIR-National Geophysical Research Institute, Hyderabad 500 007, India \\ b Agilent Technologies, CP-11, Sector-8, IMT, Manesar, Gurgaon 122 051, India \\ c National Centre for Antarctic and Ocean Research, Headland Sada, Vasco-da-Gama, Goa 403 804, India \\ d Agilent Technologies, 679 Springvale Road, Mulgrave Vic 3170, Australia \\ e Department of Chemistry, Sri Venkateswara University, Tirupati 517 502, India
}

\begin{abstract}
Accurate and reliable analytical techniques and methodologies possessing high sensitivity and selectivity, coupled with convenience and economy and applicable to real-world situations, are required for geochemical studies. Quantitative analysis of major, minor, and some trace elements were performed in several geochemical reference samples using a new microwave plasma-atomic emission spectrometry (MP-AES) technique. A range of rock, soil, sediment, and water reference materials were chosen to evaluate the performance of this technique. A set of sample decomposition/digestion methods, which included a closed digestion technique utilizing a multi-acid mixture in a closed vessel and a fusion digestion technique utilizing lithium meta-borate in a glassy carbon crucible, were used for the determination of all major and minor elements in addition to $\mathrm{Si}$, and more than 15 trace elements in sample
\end{abstract}

solutions at the $\mathrm{ng} / \mathrm{g}$ and sub$\mathrm{ng} / \mathrm{g}$ levels. Matrix interference effects encountered from concomitant elements, acid type and concentration, calibration strategies adopted, detection limits, accuracy and precision obtained were discussed. The analytical wavelengths selected were based on sensitivity and interference effects from other concomitant elements present in different sample solutions.

The detection limits for several elements were found to be in the 0.05 to $5 \mathrm{ng} / \mathrm{g}$ range, which approached those of an ICP-AES technique but were much superior to flame AAS. Precisions of $\leq 3 \%$ RSD were obtained for major and minor elements and $\leq 6 \%$ RSD for trace elements with comparable accuracies for most determinations. The results obtained in this study clearly indicate that MP-AES is a suitable atomic emission spectrometry technique for the accurate determination of major, minor, and selected trace elements required in geochemical studies.

\section{INTRODUCTION}

Scientific and technological revolutions are always very closely associated with either a new material or a new investigating analytical tool. Among these two, perhaps the analytical instrument plays a dominant role since an analytical tool is ultimately the key to characterizing the materials. In addition, the rapid and constant developments of human activities have

*Corresponding autbor.

:E-mail: balaram1951@yaboo.com increased the need for chemical characterization of different materials for their major, minor, trace and ultra-trace constituents. It enables important decisions to be made daily in varied fields, such as science, technology, industry, trade, environment, health, economy, and legal affairs. In earth science studies including mineral exploration, several earth materials, such as rocks, ores, soils, sediments and water, have to be analyzed for their major, minor, and trace constituents using different instrumen- tal analytical techniques. The past seven decades have seen a succession of advanced instrumental analytical techniques for chemical analysis particularly in the fields of geology, industry, agriculture, and the environment. Some of these are (a) flame and graphite furnace atomic absorption spectrometry (FAAS and GFAAS), (b) X-ray fluorescence spectrometry (XRF), (c) instrumental neutron activation analysis (INAA), (d) inductively coupled plasma atomic emission spectrometry (ICP-AES), (e) inductively coupled plasma mass spectrometry (ICP-MS), (f) inductively coupled plasma time of flight mass spectrometry (ICP-TOF-MS), and (g) sector field or high resolution inductively coupled plasma mass spectrometry (HR-ICP-MS), most of which have the capability to carry out rapid multi-element/isotopic analysis at and below ng/g levels (1-8).

The recently introduced microwave plasma atomic emission spectrometry (MP-AES) represents yet another very important addition to this array of analytical techniques (9). Microwave-induced plasma (MIP) has received considerable attention during the past three decades as an alternative powerful excitation source (10-16). Different gases such as hydrogen, argon, helium, neon, nitrogen, and even combinations of some of these gases were successfully utilized for producing microwave plasmas. In this direction, Hammer (9) developed a novel magnetically excited MIP emission source. Unlike previous MIP sources, which coupled energy from the microwave electric 
field, this source coupled energy from the magnetic field. The resultant plasma shape allowed easy entrainment of wet sample aerosol into the core of the plasma, such as was produced by a conventional ICP nebulizer and spray chamber. In our earlier studies (17), this technique was utilized for the generation of precise data of precious metals, gold, silver, platinum, and palladium in some rock and ore materials for mineral exploration studies. In this study, an attempt is made to summarize the performance characteristics of MP-AES and its potential as an anatical tool in geochemical studies with some practical examples from this area.

\section{EXPERIMENTAL}

\section{Instrumentation}

The Agilent ${ }^{\circledR} 4100$ MP-AES instrument was used in these studies (Agilent Technologies, USA). This is a fast sequential multi-element analytical instrument using a microwave excitation assembly to create a concentrated axial magnetic field around a conventional torch. This focuses and contains the microwave energy where it is needed to produce toroidal plasma with a cooler central channel which is suitable for stable introduction of liquid samples with a conventional sample introduction system. More details of the MP atomic source, optical system and detector of the instrument, are provided elsewhere (9). The emission intensities for different elements studied depends on gas flow, sample flow rate, and microwave power. The plasma gas flow, nebulizer gas flow, observation height, and other operating parameters were optimized for obtaining higher stability of the plasma and maximum emission intensity. The optimum operating parameters and other instrumental details such as the optical resolution of the instrument are presented in Table I.

\section{Principle}

The basic aim of any analytical atomic spectroscopy technique is to identify elements and quantify their concentrations in different kinds of materials. The principle of this technique is similar to any other emission technique such as flame emission or the well-known ICP-AES. The intensity of each emitted line will be directly proportional to the concentration of a particular element. Few steps are involved in this procedure such as sample introduction into the high temperature source, atom formation, excitation and emission,

TABLE I

Operating Parameters of MP-AES

\section{Instrumentation}

\section{Plasma Conditions}

Plasma Gas

Power of Magnetron Output

\section{Gas Flows}

Plasma Gas Flow-Nitrogen
Intermediate Flow-Nitrogen
Pre-optics Protection (POP) Gas -Air
Nebulizer Pressure

Nebulizer

Spray Chamber

Solution Uptake

Pump Tubing

Plasma Torch

Plasma Viewing

\section{Data Acquisition Parameters}

Sample Uptake Delay
Stabilization Time
Read Time
No. of Replicates
Background Ccorrection
Optical System

Optical Resolution

Detector

Analytes (Wavelengths)
Agilent 4100 Microwave Plasma AES with 4107 Nitrogen Generator

$\mathrm{N}_{2}$ by using both Air Compressor and $\mathrm{N}_{2}$ Generator (air compressor feeds the air to the $\mathrm{N}_{2}$ generator) Alternately, $\mathrm{N}_{2}$ gas cylinder or liquid $\mathrm{N}_{2}$ Dewar can also be used $1 \mathrm{~kW}$

$20 \mathrm{~L} / \mathrm{min}$

$1.1 \mathrm{~L} / \mathrm{min}$

$25 \mathrm{~L} / \mathrm{min}$

140-240 kPa (Optimize each group of elements)

OneNeb $^{\mathrm{TM}}$ inert concentric for $\mathrm{HF}$ and high TDS solutions

Double-pass glass cyclonic

$1.4 \mathrm{~mL} / \mathrm{min}$ (pumped)

$1.02 \mathrm{~mm}$ i.d. PVC

Quartz torch

Axial

$8 \mathrm{~s}$

$15 \mathrm{~s}$

$5 \mathrm{~s}$

3

Auto or FLIC (Fast Linear Interference Correction)

Czerny-Turner monochromator with $600 \mathrm{~mm}$ focal length and fixed entrance slit $<0.050 \mathrm{~nm}$ (measured as full width at half maximum).

Back thinned solid state CCD detector (532 x 128 pixels)

Data as shown in Tables III to VI 


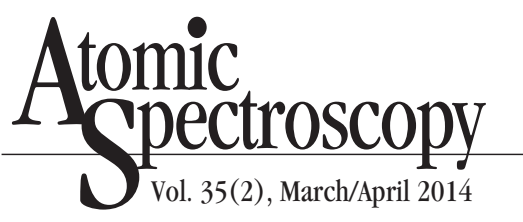

measurement of the emitted light intensity of a particular element of interest at a specified wavelength, and computation of the concentration by comparing it with that of a known concentration. MP-AES also involves the measurement of electromagnetic radiation emitted from the atoms (Figure 1). Liquid and gas samples may be injected directly into the instrument, while solid samples require samples to be in solution form. The sample solution is converted to an aerosol and directed into the central channel of the plasma. A schematic diagram of the principle of MP-AES is shown in Figure 1. More details are provided by Hammer (9).

\section{Geological and Environmental Reference Materials Used}

A range of geological and environmental materials (Table II) were utilized to study and understand the potential of this technique for geochemical and environmental applications.

\section{Sample Decomposition Methods}

For Major, Minor, and Trace Elements in Rocks, Soils, and Sediments

A $0.5 \mathrm{~g}$ sample was digested in a closed Savillex vessel (Savillex Corporation, USA) with $20 \mathrm{~mL}$ $\mathrm{HF}: \mathrm{HNO}_{3}: \mathrm{HClO}_{4}: \mathrm{HCl}(7: 3: 1: 1)$ and kept on a hot plate at $1300{ }^{\circ} \mathrm{C}$ for 30 hours (to ensure $100 \%$ dissolu-

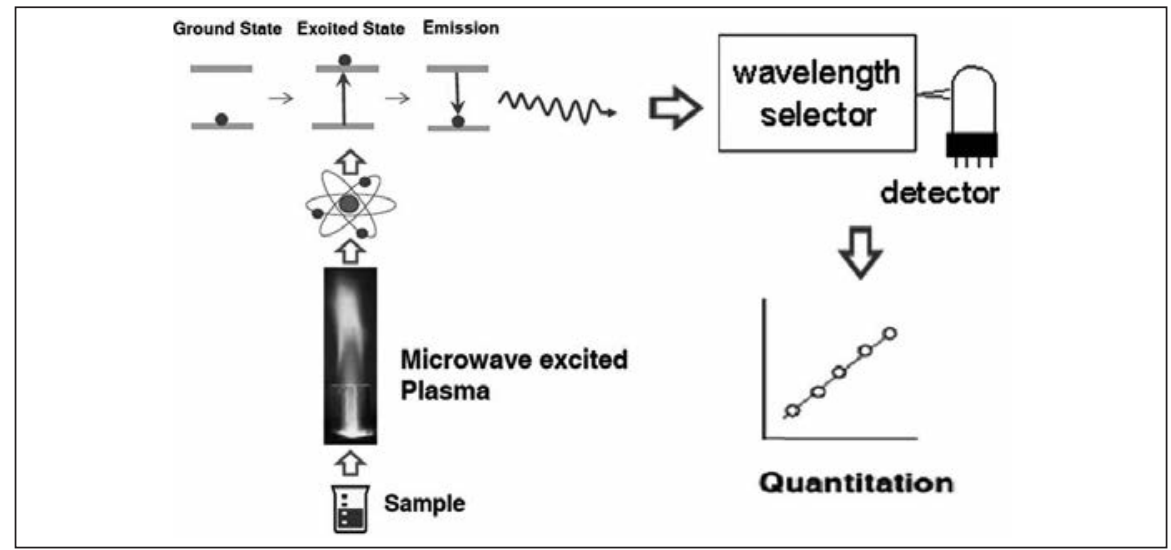

Fig. 1. Schematic diagram explains the principle of microwave plasma atomic emission spectrometry (MP-AES). Instrument used is also shown.

TABLE II

Details of Geological and Environmental Reference Materials Used in This Study

\begin{tabular}{|c|c|c|c|}
\hline S. No. & Sample & Rock Type & Source \\
\hline 1 & MRG-1 & Gabbro & $\begin{array}{l}\text { CCRMP-CANMET-MMSL (NRCan), } \\
\text { Ottawa, ON, Canada }\end{array}$ \\
\hline 2 & SY-2 & Syenite & CCRMP-CANMET-MMSL (NRCan) \\
\hline 3 & SO-1 & Soil & CCRMP-CANMET-MMSL (NRCan) \\
\hline 4 & SARM-39 & Kimberlite & $\begin{array}{l}\text { MINTEK, Randburg, Republic of South } \\
\text { Africa }\end{array}$ \\
\hline 5 & JLK-1 & Lake Sediment & $\begin{array}{l}\text { Geological Survey of Japan, Tsukuba, } \\
\text { Ibaraki, Japan }\end{array}$ \\
\hline 6 & JSD-1 & Stream Sediment & Geological Survey of Japan- \\
\hline 7 & JG-2 & Granite & Geological Survey of Japan- \\
\hline 8 & BHVO-1 & Basalt & $\begin{array}{l}\text { United States Geological Survey, Denver, } \\
\text { CO, USA }\end{array}$ \\
\hline
\end{tabular}

tion). Finally, the vessels were opened, the acid content was evaporated to near dryness, the residue dissolved in $10 \mathrm{~mL}$ of $1: 1$ nitric acid, and the final volume made up to $100 \mathrm{~mL}$ ( $5 \%$ acid solution) with Millipore ${ }^{\circledR}$ Milli-Q ${ }^{\mathrm{TM}}$ water (18 M $\Omega$ ), then stored in 60-mL bottles as described by Balaram et al. (18). All samples studied in this investigation yielded clear solutions.

\section{Fusion Decomposition Method}

A $0.1 \mathrm{~g}$ sample and $0.5 \mathrm{~g}$ lithium metaborate were weighed, mixed thoroughly, transferred into a glassy carbon crucible $(10 \mathrm{~mL})$, and fused at $1050{ }^{\circ} \mathrm{C}$ for 30 minutes in a muffle furnace. The crucible was cooled and the separated bead transferred into a beaker with $25 \mathrm{~mL}$ of $10 \%$ $\mathrm{HNO}_{3}$ solution. The solution was continuously stirred with a magnetic stirrer for about 20 minutes for complete dissolution of the bead. The solutions were made up to $100 \mathrm{~mL}$ with Millipore water (18 $\mathrm{M} \Omega$ ) and filtered to remove any suspended carbon particles, then stored in $60-\mathrm{mL}$ polyethene bottles. More details on the fusion sample preparation are provided by Roy et al. (19).

\section{Analysis}

During the analysis, the nebulizer system was washed with $1 \%$ $\mathrm{HNO}_{3}$ and Millipore water for 40 seconds. The data on each sample were acquired after 60 seconds of nebulization to stabilize the plasma. Procedural blanks, calibration, sample and reference sample solutions were analyzed in that order.

\section{RESULTS AND DISCUSSION}

In recent years, MP-AES has slowly been emerging as one of the most powerful and popular analytical tools for the analysis of different materials. As already described, this technique is also based on the spontaneous emission of photons from atoms and ions that have been excited in magnetically excited microwave nitrogen 
plasma (20). All commonly used analytical atomic emission techniques in general suffer from various kinds of interferences and MP-AES is no exception. But MP-AES has relatively less interferences. The nitrogen plasma is inert when compared to the chemical reactivity of various other flames used, particularly in atomic absorption spectrometry. Also the high temperature of the microwave plasma helps to reduce chemical interferences. The temperature is high enough to break down most species into atoms or ions for excitation and subsequent emission.

\section{Effect of Major and Minor Element Concentrations on the Signals of Trace Elements}

The vast majority of crustal rocks contain about 10 major and minor elements, namely (in decreasing order of abundance) $\mathrm{Si}, \mathrm{Al}, \mathrm{Fe}, \mathrm{Ca}$, $\mathrm{Na}, \mathrm{K}, \mathrm{Mg}, \mathrm{Mn}, \mathrm{Ti}, \mathrm{Fe}, \mathrm{Ca}, \mathrm{Mg}, \mathrm{Na}$, $\mathrm{K}, \mathrm{Mn}$, and $\mathrm{P}$. Very high concentrations of these elements will have enhancement/suppression (matrix) effects on the signals of various trace elements. In order to understand these effects in MP-AES, a systematic study was carried out and the results are presented in Figure 2. A few trace elements ( $\mathrm{Bi}, \mathrm{Tb}, \mathrm{Sc}, \mathrm{Y}$, In, $\mathrm{Cu}, \mathrm{Co}, \mathrm{Mo}$, and $\mathrm{Li}$ ) across the periodic table were selected and the effects of different major and minor elements on each trace element were studied. The concentration of different trace elements was kept at $2 \mu \mathrm{g} / \mathrm{mL}$ and the concentrations of various major and minor elements were varied from 25 to $500 \mu \mathrm{g} / \mathrm{mL}$. These are the concentrations of the elements normally encountered in real rock sample solutions (after the required dilutions) used for chemical analysis. The effect of Si was not studied since most rock decomposition procedures involve elimination of Si by adding HF. From the results presented in Figure 2 it is evident that alkali and alkaline earth elements showed severe enhancement effects in general on the MPAES signals of different trace elements as these easily ionizable elements can improve vaporization and atomization conditions in the plasma. Aluminum, iron, titanium, and manganese also behaved in a similar way. The enhancement effects are also increasing with the concentrations of different major and minor elements. Phosphorous is an exception since its concentration generally has very little effect on the signals of different trace elements. These results indicate that the major and minor element concentrations will have enhancing effects on the signals of different trace elements and it is very difficult to quantify these effects on a particular trace element or a set of trace elements. The matrix effects in high-power nitrogen MIP were extensively studied by Zhang and Wagatsuma (21) under a variety of conditions. Based on the matrix effects, and the results of the excitation temperature and the electron number density measurements, it was concluded that the effects of $\mathrm{Na}$ and $\mathrm{Ca}$ were primarily attributed to the shift in the atom/ion ionization equilibrium resulting from a decrease in plasma temperature and an increase in electron number density. Similar effects were also noticed in the analysis of geological materials by ICP-MS recently (22)

\section{Effect of Acid Concentration on the Signals of Trace Elements}

The effect of acid concentration on the signals of some elements was also studied and the results are presented in Figure 3. These studies were carried out on $2 \mu \mathrm{g} / \mathrm{mL}$ multi-element solution ( $\mathrm{Li}, \mathrm{Na}, \mathrm{Ba}$, Cr, Ni, Mn, B, Fe, Ga, Bi, Zn, In, Mg, $\mathrm{Cd}, \mathrm{Ca}, \mathrm{Sr}, \mathrm{Cu}, \mathrm{Ag}, \mathrm{Co}, \mathrm{Tl}, \mathrm{Al}, \mathrm{K}, \mathrm{Pb}$ ) prepared in different acid concentrations $(1-10 \%)$. Some interesting observations were made. Up to about $5 \% \mathrm{HNO}_{3}$ concentration, there is no effect on the signals for the different elements. Above 5\% $\mathrm{HNO}_{3}$ concentration, there is a slight enhancing effect, and afterwards a gentle depression in the signal was observed for the majority of the elements. On the other hand, the $\mathrm{HCl}$ and $\mathrm{HClO}_{4}$ concentrations show a slight enhancement effect with an increase in the acid concentration on the signals of all elements studied. $\mathrm{H}_{3} \mathrm{PO}_{4}$ has a slight depressing effect on the signals of several elements with an increase in acid concentration. It is possible that anions such as $\mathrm{SO}_{4}{ }^{2-}$ and $\mathrm{PO}_{4}{ }^{3-}$ will react with analytes to produce a species of low volatility in the plasma and this can significantly reduce ion/atom population of the analytes. As a result, there will be depression in the signals of the analytes. The effect of $\mathrm{H}_{2} \mathrm{SO}_{4}$ was not studied as it was causing precipitations when added to the multi-element solution. These studies indicated that $\mathrm{HNO}_{3}$ is the best acid for use in sample preparations for MP-AES work.

\section{Calibration Strategies and Linearity of Calibration Curves}

One of the major considerations in any analytical spectroscopy is the method of calibration. In general, all the acids studied here have shown considerable influence on the signals of the individual elements. The effects related to acid concentrations can only be minimized and not totally eliminated as the acid concentration can be controlled during the sample preparation as well as the analysis. On the other hand, there is no control on the concentrations of different major and minor elements in individual sample solutions. Hence, it will be difficult to eliminate these interference effects. In order to overcome these types of matrix effects generally observed during the analysis of geological samples, several methods can be used. Use of identically prepared matrix 


\section{A Spectroscopy $_{\text {pect }}$ \\ Vol. 35(2), March/April 2014}

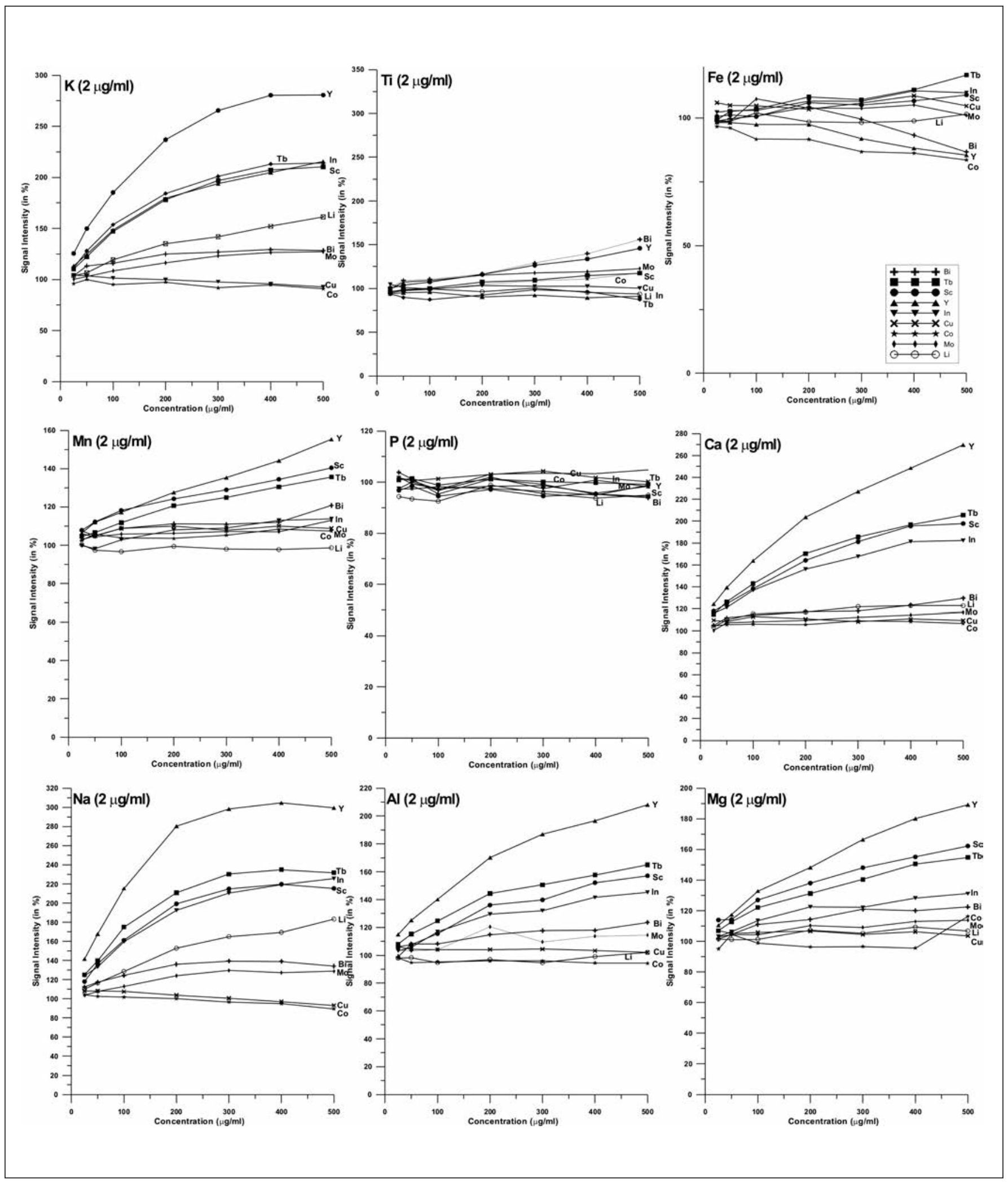

Fig. 2. Effect of concomitant (matrix) elements on the MP-AES signals of some elements. 


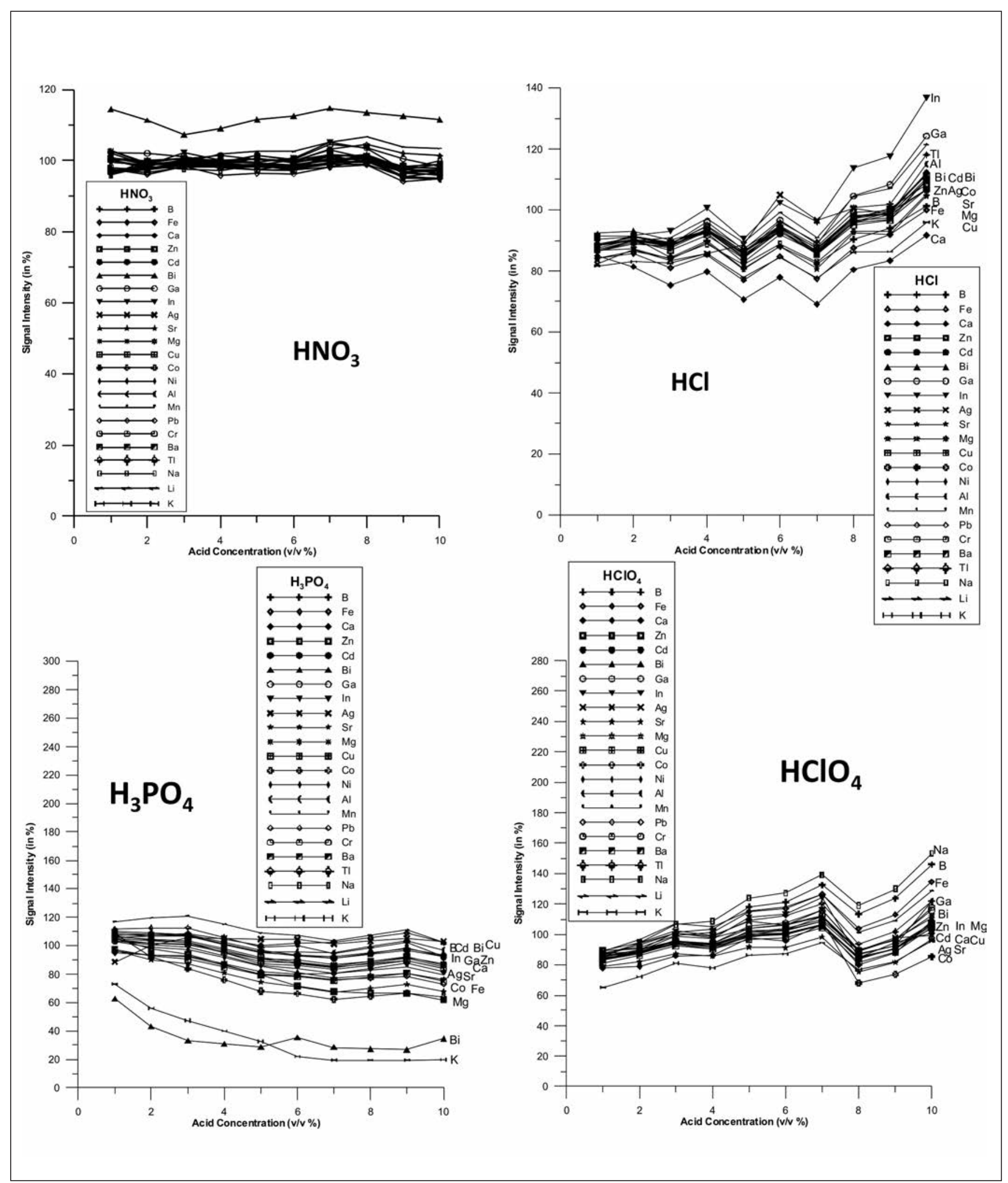

Fig. 3. Effect of acid concentration on the MP-AES signals of some elements. 
matching certified reference materials (CRMs) for calibration is one of the ways to minimize the matrix interferences as described above and to obtain reasonably accurate data in geochemical studies. This study also suggests that the major and minor element composition of the CRMs used for calibration and the sample must match as closely as possible. A few CRMs should also be analyzed as control samples to monitor the accuracy of the determinations. This is a convenient and safe approach, especially when a few other reference materials are being analyzed as unknowns, although it is difficult to obtain more than one rock certified reference material (CRM) of the same chemical composition.

It has been observed that MPAES calibration curves are in general linear over four orders of magnitude for several elements. Figure $4 \mathrm{a}$ presents calibration curves for the elements In and $\mathrm{Bi}$ which are linear for a wide range of concentrations. A similar calibration curve obtained for Co is not very much linear. It may be a good idea to use the most sensitive wavelengths for determining very low concentrations and the other wavelengths for the determination of different elements at appropriate higher concentration levels (Figure 4b). The analytical wavelengths for different elements in this study were selected by considering the sensitivity and the interference effects from other concomitant elements present in different sample solutions. Earlier studies (17) have also indicated that MP-AES provides good linear calibrations for elements such as Au and Ag; hence, a single calibration standard is sufficient for the accurate measurement of trace and ultra-trace elements in geological materials. In this study, the instrument was calibrated with SO-1 for the analysis of soils and sediments; SY-2 was used for cali-

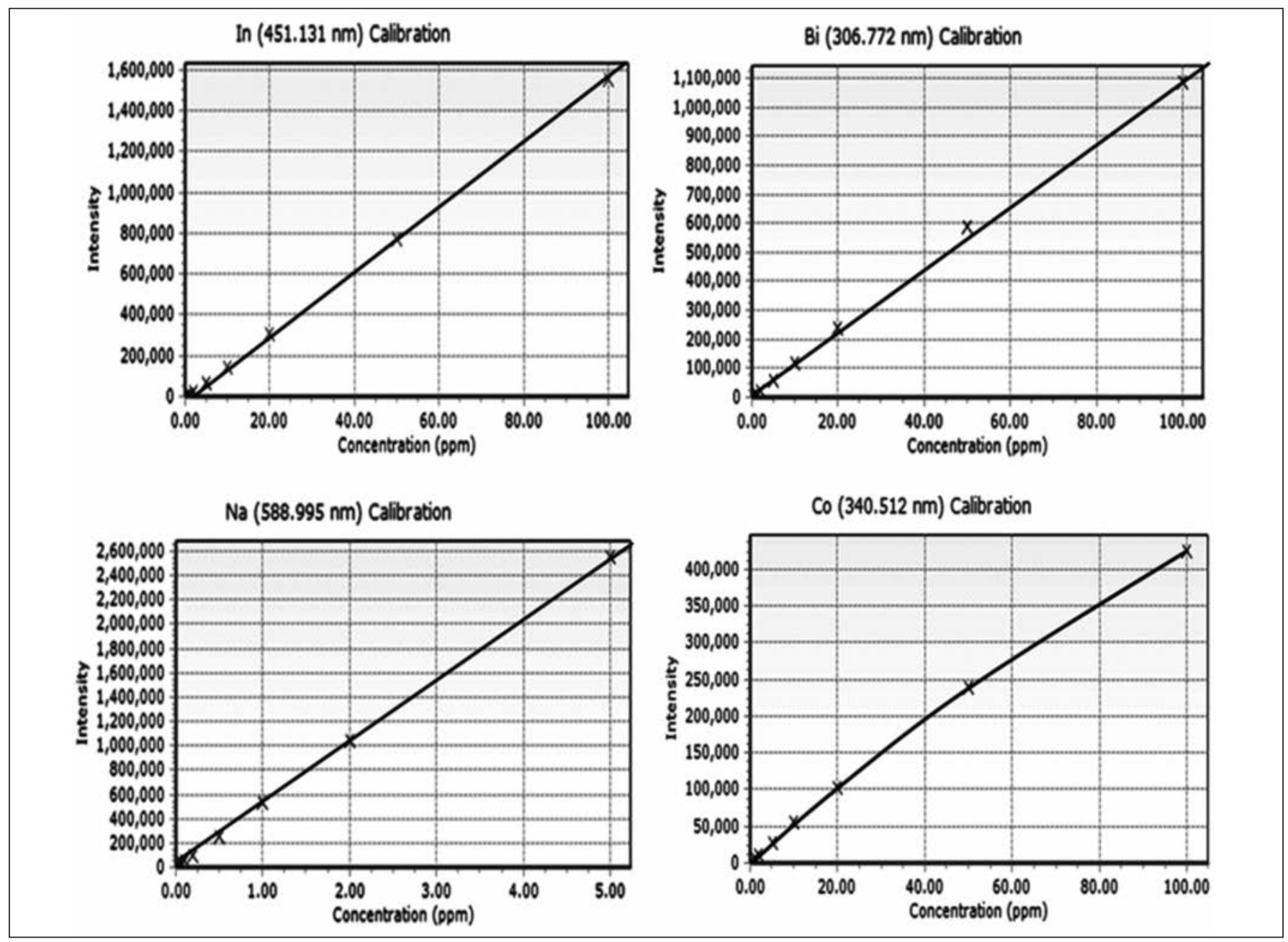

Fig. 4a. Calibration curves for few elements at different wavelengths in MP-AES. 

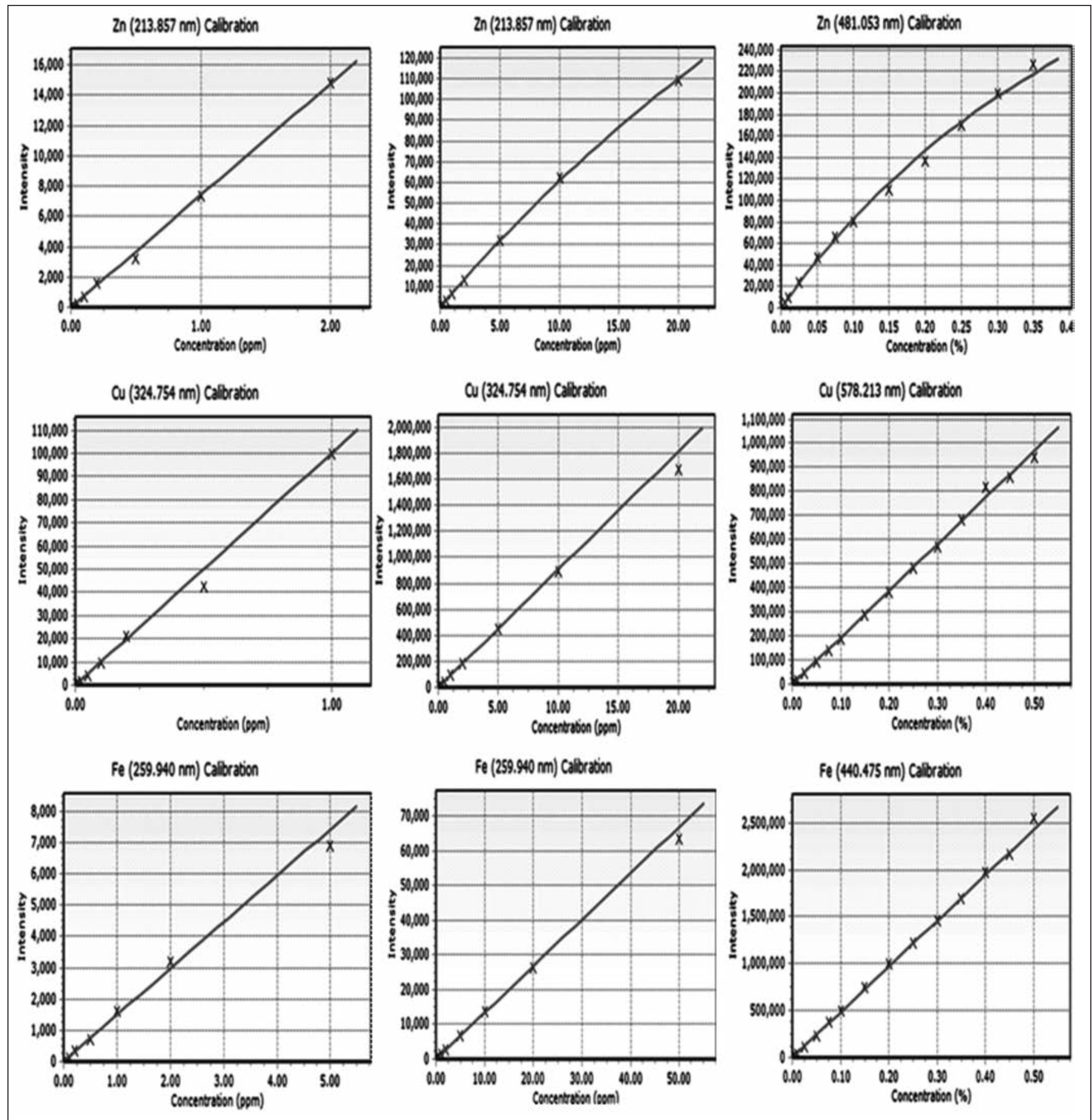

Fig. 4b. Calibration curves for several elements at different wavelengths in MP-AES. $\mathrm{Zn}(213.857 \mathrm{~nm})$ and $\mathrm{Zn}(481.053 \mathrm{~nm})$.

$\mathrm{Cu}(324.754 \mathrm{~nm})$ and $\mathrm{Cu}(578.213 \mathrm{~nm})$.

$\mathrm{Fe}(259.940 \mathrm{~nm})$ and $\mathrm{Fe}(440.475 \mathrm{~nm})$. 


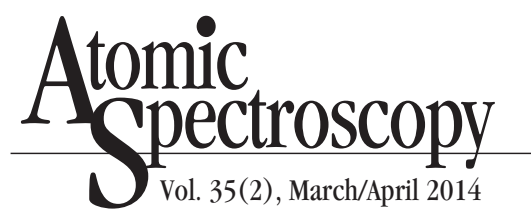

bration for the analysis of rock samples, and the NIST 1640a reference water sample for water analysis (National Institute of Standards and Technology, Gaitherburg, MD,

USA). Figures $5 \mathrm{a}$ and $5 \mathrm{~b}$ are the sin- gle-point calibration curves obtained for some elements by using SY-2 and SO-1. As discussed earlier, this is a safe approach particularly when some international reference materials with known values for different elements are also analyzed as unknowns. Concentrations ( $w \mathrm{t} \%$ or $\mu \mathrm{g} / \mathrm{g}$ or $\mathrm{ng} / \mathrm{mL}$ ) of the elements were measured in the sample solutions after applying blank corrections.

\section{(a) Calibration curves using SY-2}
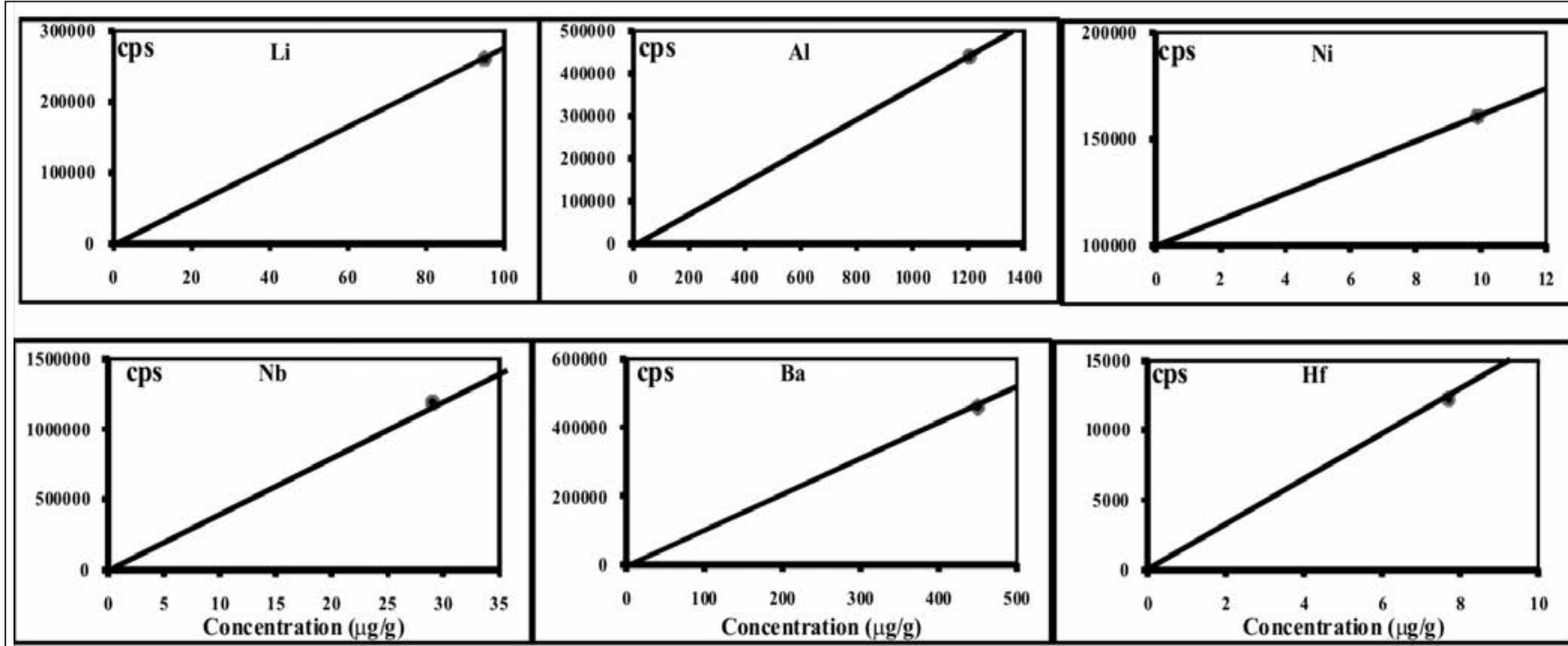

(b) Calibration curves using SY-2
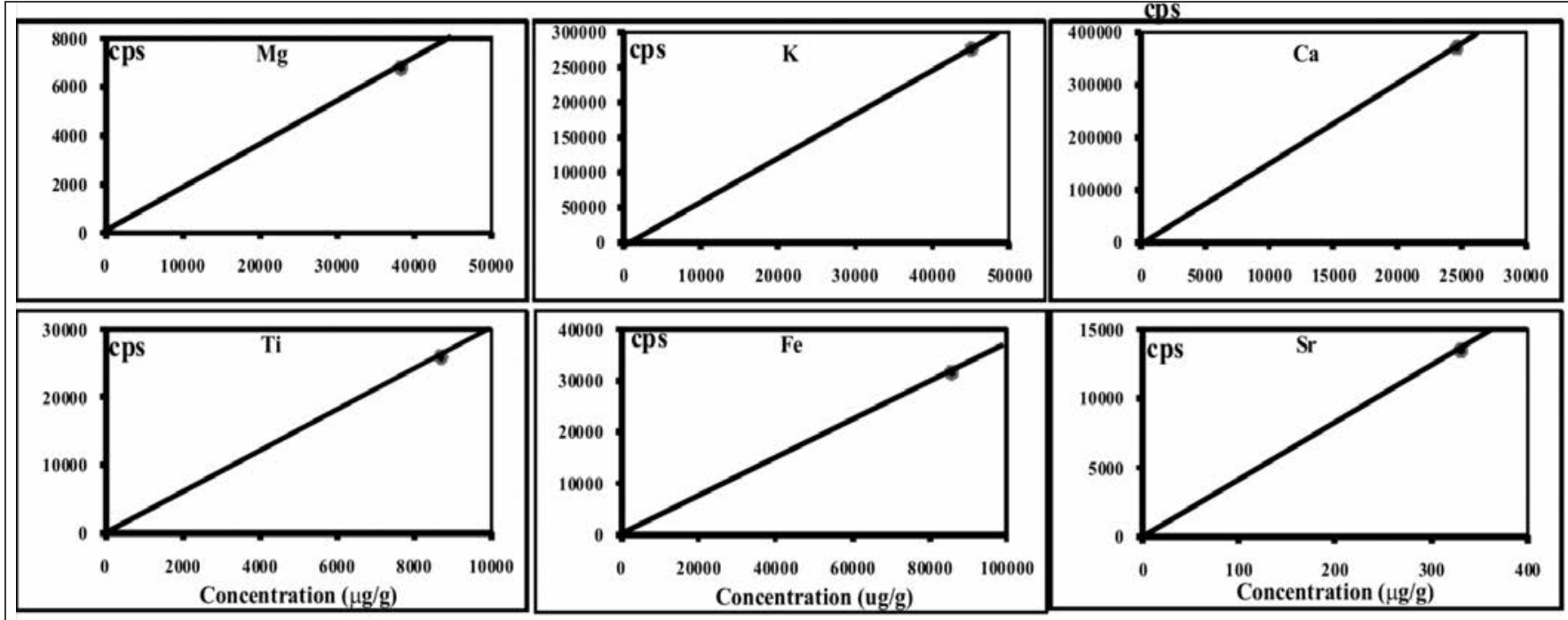

Fig. $5 a$ and $b$. Several practical examples of calibration curves used for obtaining concentrations of different elements in rock, soil and sediment reference material samples in this study. 
Analytical Performance in the Analysis of Geochemical Samples

Most of the rocks are made up of $\mathrm{SiO}_{2}, \mathrm{Al}_{2} \mathrm{O}_{3}, \mathrm{Fe}_{2} \mathrm{O}_{3}, \mathrm{FeO}, \mathrm{MnO}$, $\mathrm{MgO}, \mathrm{CaO}, \mathrm{Na}_{2} \mathrm{O}, \mathrm{K}_{2} \mathrm{O}, \mathrm{TiO}_{2}, \mathrm{P}_{2} \mathrm{O}_{5}$, and $\mathrm{H}_{2} \mathrm{O}$. Several other elements such as $\mathrm{Cu}, \mathrm{Co}, \mathrm{Li}, \mathrm{Rb}, \mathrm{Sr}$, and $\mathrm{U}$ are present at extremely low concentration levels and they are trace elements. These major, minor, and trace element concentrations reveal different primary and secondary processes that these rocks have undergone (23). Therefore, accurate determination of these compositions is necessary to develop and refine models for different physico- chemical processes operating

through time and space.

In order to understand the potential of MP-AES in geochemistry, a variety of international geological reference materials comprised of basalt, gabbro, kimberlite, soil, stream and lake sediment were analyzed by MP-AES after the samples were digested by a well-tested closed sample decomposition procedure (18). Geochemical data of major, minor, and trace elements as listed in Tables III and Table IV reveal that there is very close agreement with the data obtained in this study and the reported values.

These data also show that the preci- sion obtained for major and minor elements was $\leq 3 \%$ RSD with comparable accuracy. The determinations were carried out at more than one wavelength for certain elements such as aluminum, manganese, and potassium. The data obtained at different wavelengths also very closely agree for different elements showing that these elements can be determined at all of these wavelengths and are accurate. Some geochemically important trace elements ( $\mathrm{Zn}, \mathrm{Be}, \mathrm{Ta}, \mathrm{Nb}, \mathrm{Cu}, \mathrm{Hf}, \mathrm{Zr}$, $\mathrm{Ni}, \mathrm{Sc}, \mathrm{Mo}, \mathrm{Pb}, \mathrm{Sr}, \mathrm{Ga}, \mathrm{Cr}, \mathrm{Ba}, \mathrm{Li}$, and $\mathrm{Rb}$ ) were also determined with a precision of $\leq 6 \%$ RSD and the data (Table V) compare very well with the certified values.

\section{TABLE III}

Major and Minor Oxide Data (wt \%) in International Geochemical Reference Materials Obtained by MP-AES in Comparison With Certified Values

\begin{tabular}{|c|c|c|c|c|c|c|c|c|c|c|c|c|c|c|}
\hline \multirow{3}{*}{ Sample } & \multicolumn{2}{|c|}{ P205 } & \multicolumn{2}{|c|}{ Al2O3 } & \multicolumn{2}{|c|}{$\mathrm{MnO}$} & \multicolumn{2}{|c|}{$\mathrm{MgO}$} & \multicolumn{2}{|c|}{ TiO2 } & \multicolumn{2}{|c|}{ Al2O3 } & \multicolumn{2}{|c|}{ Al203 } \\
\hline & \multicolumn{2}{|c|}{$213.618 \mathrm{~nm}$} & \multicolumn{2}{|c|}{$237.312 \mathrm{~nm}$} & \multicolumn{2}{|c|}{$257.610 \mathrm{~nm}$} & \multicolumn{2}{|c|}{$279.077 \mathrm{~nm}$} & \multicolumn{2}{|c|}{$307.523 \mathrm{~nm}$} & \multicolumn{2}{|c|}{$308.215 \mathrm{~nm}$} & \multicolumn{2}{|c|}{$309.271 \mathrm{~nm}$} \\
\hline & $\begin{array}{l}\text { This } \\
\text { Study }\end{array}$ & $\begin{array}{c}\text { "Reference } \\
\text { Value }\end{array}$ & $\begin{array}{l}\text { This } \\
\text { Study }\end{array}$ & $\begin{array}{c}\text { "Reference } \\
\text { Value }\end{array}$ & $\begin{array}{l}\text { This } \\
\text { Study }\end{array}$ & $\begin{array}{c}\text { "Reference } \\
\text { Value }\end{array}$ & $\begin{array}{l}\text { This } \\
\text { Study }\end{array}$ & $\begin{array}{c}\text { "Reference } \\
\text { Value }\end{array}$ & $\begin{array}{l}\text { This } \\
\text { Study }\end{array}$ & $\begin{array}{c}\text { "Reference } \\
\text { Value }\end{array}$ & $\begin{array}{l}\text { This } \\
\text { Study }\end{array}$ & $\begin{array}{c}\text { "Reference } \\
\text { Value }\end{array}$ & $\begin{array}{c}\text { This } \\
\text { Study }\end{array}$ & $\begin{array}{c}\text { "Reference } \\
\text { Value }\end{array}$ \\
\hline MRG-1 & 0.07 & 0.08 & 8.54 & 8.47 & 0.18 & 0.17 & 13.67 & 13.55 & 3.67 & 3.77 & 8.55 & 8.47 & 8.80 & 8.47 \\
\hline SARM-39 & 1.43 & 1.46 & 4.22 & 4.29 & 0.16 & 0.17 & 26.12 & 26.24 & 1.41 & 1.58 & 3.97 & 4.29 & 4.24 & 4.29 \\
\hline JLK-1 & 0.27 & 0.26 & 16.79 & 16.86 & 0.23 & 0.27 & 1.76 & 1.76 & 0.68 & 0.67 & 16.99 & 16.86 & 16.33 & 16.86 \\
\hline JSD-1 & 0.10 & 0.12 & 14.78 & 14.66 & 0.11 & 0.09 & 1.86 & 1.85 & 0.66 & 0.65 & 13.93 & 14.66 & 14.22 & 14.66 \\
\hline SO-1 & 0.18 & 0.15 & 17.61 & 17.59 & 0.14 & 0.11 & 3.89 & 3.83 & 0.85 & 0.87 & 18.21 & 17.59 & 17.11 & 17.59 \\
\hline JG-2 & 0.01 & 0.01 & 11.99 & 12.41 & 0.04 & 0.02 & 0.05 & 0.04 & 0.06 & 0.04 & 12.33 & 12.41 & 12.44 & 12.41 \\
\hline BHVO-1 & 0.28 & 0.27 & 14.11 & 13.80 & 0.02 & 0.02 & 7.25 & 7.23 & 2.55 & 2.71 & 13.89 & 13.80 & 13.81 & 13.80 \\
\hline \multirow{3}{*}{ Sample } & \multicolumn{2}{|c|}{$\mathrm{Fe} 2 \mathrm{O} 3$} & \multicolumn{2}{|c|}{$\mathrm{MnO}$} & \multicolumn{2}{|c|}{$\mathrm{CaO}$} & \multicolumn{2}{|c|}{$\mathrm{Fe} 2 \mathrm{O} 3$} & \multicolumn{2}{|c|}{$\mathrm{Na2O}$} & \multicolumn{2}{|c|}{ K2O } & \multicolumn{2}{|c|}{ K2O } \\
\hline & \multicolumn{2}{|c|}{$400.524 \mathrm{~nm}$} & \multicolumn{2}{|c|}{$403.307 \mathrm{~nm}$} & \multicolumn{2}{|c|}{$429.899 \mathrm{~nm}$} & \multicolumn{2}{|c|}{$440.475 \mathrm{~nm}$} & \multicolumn{2}{|c|}{$568.263 \mathrm{~nm}$} & \multicolumn{2}{|c|}{$766.491 \mathrm{~nm}$} & \multicolumn{2}{|c|}{$769.897 \mathrm{~nm}$} \\
\hline & $\begin{array}{l}\text { This } \\
\text { Study }\end{array}$ & $\begin{array}{c}\text { "Reference } \\
\text { Value }\end{array}$ & $\begin{array}{l}\text { This } \\
\text { Study }\end{array}$ & $\begin{array}{c}\text { "Reference } \\
\text { Value }\end{array}$ & $\begin{array}{l}\text { This } \\
\text { Study }\end{array}$ & $\begin{array}{c}\text { "Reference } \\
\text { Value }\end{array}$ & $\begin{array}{l}\text { This } \\
\text { Study }\end{array}$ & $\begin{array}{c}\text { "Reference } \\
\text { Value }\end{array}$ & $\begin{array}{l}\text { This } \\
\text { Study }\end{array}$ & $\begin{array}{c}\text { 'Reference } \\
\text { Value }\end{array}$ & $\begin{array}{l}\text { This } \\
\text { Study }\end{array}$ & $\begin{array}{c}\text { "Reference } \\
\text { Value } \\
\end{array}$ & $\begin{array}{l}\text { This } \\
\text { Study }\end{array}$ & $\begin{array}{c}\text { "Reference } \\
\text { Value }\end{array}$ \\
\hline MRG-1 & 18.65 & 17.94 & 0.15 & 0.17 & 13.20 & 14.70 & 18.15 & 17.94 & 0.77 & 0.74 & 0.23 & 0.18 & 0.20 & 0.18 \\
\hline SARM-39 & 9.25 & 9.29 & 0.16 & 0.17 & 9.25 & 9.69 & 8.90 & 9.29 & 0.54 & 0.50 & 1.10 & 1.04 & 1.10 & 1.04 \\
\hline JLK-1 & 6.94 & 6.84 & 0.27 & 0.27 & 0.71 & 0.68 & 6.55 & 6.84 & 0.96 & 1.00 & 2.74 & 2.77 & 2.74 & 2.77 \\
\hline JSD-1 & 4.99 & 5.11 & 0.09 & 0.09 & 2.98 & 3.07 & 4.86 & 5.11 & 2.47 & 2.73 & 2.26 & 2.19 & 2.17 & 2.19 \\
\hline SO-1 & 8.23 & 8.58 & 0.11 & 0.11 & 2.32 & 2.46 & 8.28 & 8.58 & 2.56 & 2.70 & 3.16 & 3.18 & 3.08 & 3.18 \\
\hline JG-2 & 0.89 & 0.92 & 0.02 & 0.02 & 0.79 & 0.80 & 0.86 & 0.92 & 3.51 & 3.55 & 4.44 & 4.72 & 4.55 & 4.72 \\
\hline BHVO-1 & 12.63 & 12.23 & 0.17 & 0.17 & 11.24 & 11.40 & 12.40 & 12.23 & 2.27 & 2.26 & 0.65 & 0.52 & 0.59 & 0.52 \\
\hline
\end{tabular}




\section{Atomic Apectroscopy \\ 1 Vol. 35(2), March/April 2014}

TABLE IV

Concentrations ( $\mu \mathrm{g} / \mathrm{g})$ of Selected Trace Elements in Some International Geological

Reference Materials Obtained by MP-AES in Comparison With Recommended Values

\begin{tabular}{|c|c|c|c|c|c|c|c|c|c|c|c|c|c|c|c|}
\hline \multirow[b]{2}{*}{ Element } & \multirow[b]{2}{*}{ Wavelength } & \multicolumn{2}{|c|}{ MRG-1 } & \multicolumn{2}{|c|}{ SARM-39 } & \multicolumn{2}{|c|}{ JLK-1 } & \multicolumn{2}{|c|}{ JSD-1 } & \multicolumn{2}{|c|}{ SO-1 } & \multicolumn{2}{|c|}{ JG-2 } & \multicolumn{2}{|c|}{ BHVO-1 } \\
\hline & & \begin{tabular}{|l|} 
This \\
Study
\end{tabular} & RV & \begin{tabular}{|c|} 
This \\
Study
\end{tabular} & RV & \begin{tabular}{|c|} 
This \\
Study \\
\end{tabular} & $\mathrm{RV}$ & $\begin{array}{l}\text { This } \\
\text { Study }\end{array}$ & $\mathrm{RV}$ & $\begin{array}{l}\text { This } \\
\text { Study }\end{array}$ & RV & $\begin{array}{l}\text { This } \\
\text { Study }\end{array}$ & RV & $\begin{array}{l}\text { This } \\
\text { Study }\end{array}$ & RV \\
\hline $\mathrm{Zn}$ & $213.857 \mathrm{~nm}$ & 204.08 & 191 & 74.71 & 70 & 159.64 & 151 & 105.86 & 99 & 146.65 & 144 & 12.39 & 12.7 & 109.03 & 105 \\
\hline $\mathrm{Be}$ & $234.861 \mathrm{~nm}$ & ND & & ND & & ND & & 1.61 & 1.3 & 2.01 & 1.98 & 2.51 & 2.5 & ND & \\
\hline $\mathrm{Ta}$ & $268.517 \mathrm{~nm}$ & $\mathrm{ND}$ & & ND & & $\mathrm{ND}$ & & $\mathrm{ND}$ & & $\mathrm{ND}$ & & 1.87 & 1.9 & 1.55 & 1.23 \\
\hline $\mathrm{Nb}$ & $309.418 \mathrm{~nm}$ & 21.77 & 20 & ND & & ND & & ND & & ND & & 18.22 & 15 & 20.1 & 19 \\
\hline $\mathrm{Cu}$ & $324.754 \mathrm{~nm}$ & 141.66 & 134 & 60.69 & 58 & ND & & 14.58 & 22 & 55.99 & 61 & ND & & 150.54 & 136 \\
\hline $\mathrm{Hf}$ & $339.980 \mathrm{~nm}$ & 3.74 & 3.76 & ND & & ND & & ND & & ND & & 4.38 & 4.7 & 11.41 & 4.38 \\
\hline $\mathrm{Zr}$ & $343.823 \mathrm{~nm}$ & 111.76 & 108 & 234.83 & 239 & 151 & 146 & ND & & 82.49 & 84 & 97.01 & 101 & 177.27 & 179 \\
\hline $\mathrm{Ni}$ & $352.454 \mathrm{~nm}$ & $\mathrm{ND}$ & & ND & & ND & & 7.51 & 6.9 & $\mathrm{ND}$ & & 1.4 & 2.1 & $\mathrm{ND}$ & \\
\hline Sc & $361.383 \mathrm{~nm}$ & ND & & ND & & ND & & ND & & $\mathrm{ND}$ & & 3.08 & 2.47 & $\mathrm{ND}$ & \\
\hline Mo & $379.825 \mathrm{~nm}$ & 1.07 & 0.87 & 5.61 & 5 & ND & & ND & & ND & & 0.12 & 0.23 & 1.66 & 1.02 \\
\hline $\mathrm{Pb}$ & $405.781 \mathrm{~nm}$ & ND & & ND & & 47.02 & 45 & $\mathrm{ND}$ & & 22.87 & 20 & 34.88 & 32.8 & ND & \\
\hline $\mathrm{Sr}$ & $407.771 \mathrm{~nm}$ & 267.67 & 266 & 1388.8 & 1400 & 67.46 & 69 & 287.26 & 323 & 315.48 & 331 & 14.63 & 16 & 393.67 & 403 \\
\hline $\mathrm{Ga}$ & $417.204 \mathrm{~nm}$ & 15.97 & 17 & 24.61 & 10 & ND & & $\mathrm{ND}$ & & 30.33 & 24.1 & 14.03 & 18.6 & 23.44 & 21 \\
\hline $\mathrm{Cr}$ & $425.433 \mathrm{~nm}$ & 422.93 & 430.59 & 1278.9 & 1300 & 64.41 & 69 & 19.21 & 22 & 174.39 & 170 & 7.29 & 7.6 & 275.7 & 289 \\
\hline $\mathrm{Ba}$ & $455.403 \mathrm{~nm}$ & 57.08 & 61 & 1677.8 & 1700 & $\mathrm{ND}$ & & $\mathrm{ND}$ & & 850.57 & 870 & 56.31 & 67 & 122.58 & 139 \\
\hline $\mathrm{Li}$ & $670.784 \mathrm{~nm}$ & 4.88 & 4.2 & ND & & 49.59 & 54.7 & 26.83 & 24.2 & 45.28 & 48 & 42.55 & 43.4 & 4.63 & 4.6 \\
\hline $\mathrm{Rb}$ & $780.027 \mathrm{~nm}$ & 10.6 & 8.5 & 48.53 & 52 & 137.91 & 144 & 66.79 & 65 & 133.84 & 141 & 303.11 & 297 & 12.55 & 11 \\
\hline
\end{tabular}

$\mathrm{ND}=$ not determined. $\quad *(26) \quad$ Precisions $\leq 6 \% \mathrm{RSD} . \quad \mathrm{n}=6$

TABLE V

MP-AES Results (wt $\%)$ of Some Major and Minor Elemental Oxides

in International Geological and Environmental Reference Materials

Following the Lithium Meta-borate Fusion Sample Digestion Procedure in Comparison With Certified Data

\begin{tabular}{|c|c|c|c|c|c|c|c|c|c|c|c|c|}
\hline \multirow{3}{*}{ Sample } & \multicolumn{2}{|c|}{ Al203 } & \multicolumn{2}{|c|}{ TiO2 } & \multicolumn{2}{|c|}{$\mathrm{Fe} 2 \mathrm{O} 3$} & \multicolumn{2}{|c|}{$\mathrm{MnO}$} & \multicolumn{2}{|c|}{ K2O } & \multicolumn{2}{|c|}{$\mathrm{SiO2}$} \\
\hline & \multicolumn{2}{|c|}{$237.312 \mathrm{~nm}$} & \multicolumn{2}{|c|}{$307.523 \mathrm{~nm}$} & \multicolumn{2}{|c|}{$400.524 \mathrm{~nm}$} & \multicolumn{2}{|c|}{$403.307 \mathrm{~nm}$} & \multicolumn{2}{|c|}{$769.897 \mathrm{~nm}$} & \multicolumn{2}{|c|}{$251.611 \mathrm{~nm}$} \\
\hline & This study & $\mathrm{RV}^{*}$ & This study & $\mathrm{RV}^{*}$ & This study & $\mathrm{RV}^{*}$ & This study & $\mathrm{RV}^{*}$ & This study & $\mathrm{RV}^{*}$ & This study & $\mathrm{RV}^{*}$ \\
\hline MRG-1 & 8.03 & 8.47 & 3.56 & 3.77 & 18.73 & 17.94 & 0.17 & 0.17 & 0.16 & 0.18 & 39.55 & 39.12 \\
\hline SARM-39 & 4.59 & 4.29 & 1.47 & 1.58 & 9.74 & 9.29 & 0.16 & 0.17 & 1.2 & 1.04 & 33.78 & 33.44 \\
\hline JLk-1 & 16.22 & 16.86 & 0.62 & 0.67 & 6.8 & 6.84 & 0.25 & 0.27 & 2.85 & 2.77 & 56.97 & 57.09 \\
\hline JSd-1 & 14.02 & 14.66 & 0.63 & 0.65 & 4.83 & 5.11 & 0.09 & 0.09 & 2.29 & 2.19 & 64.78 & 66.42 \\
\hline JG-2 & 12.51 & 12.41 & 0.02 & 0.04 & 0.81 & 0.92 & 0.01 & 0.02 & 4.61 & 4.72 & 77.44 & 76.95 \\
\hline BHVO-1 & 12.2 & 13.8 & 2.75 & 2.71 & 11.88 & 12.23 & 0.16 & 0.17 & 0.6 & 0.52 & 49.78 & 49.94 \\
\hline
\end{tabular}

S0-1 was used as a calibration standard. Reference Values (RV) are from (26) $n=6$; Precision $<6 \%$ RSD 
When acid dissolution procedures are adopted to dissolve geological samples, $\mathrm{Si}$ is normally expelled by the addition of HF. As a result, it is not possible to determine silica from those solutions. Therefore, a fusion digestion method was employed using lithium metaborate for the determination of $\mathrm{Si}$. In addition to $\mathrm{Si}$, six other elements were also determined in terms of their oxides from these solutions. SO-1 was used as calibration standard. Very dilute solutions $(0.6 \% \mathrm{wt})$ were analyzed and the data obtained agree very well with the reported data for all these elements (Table V). The data on the international geological reference material BHVO-1 (USGS, India) presented in Figure 6 exhibits very good agreement between the certified values $(\mu \mathrm{g} / \mathrm{g})$ and the values obtained in this study by MP-AES for the various major, minor, and some trace elements. In addition, the data of selected major, minor, and trace elements determined in tap water ( $\mathrm{ng} / \mathrm{mL}$ ) from the Mulgrave area, Victoria, Australia, were also analyzed by MP-AES with a precision of $\leq 6 \%$ RSD. The results are presented in comparison with permissible limits set by WHO in Table VI.

\section{Detection Limits}

The limit of detection (LOD) will suffer especially when different metals at trace concentration levels are present in a high matrix of easily ionizable elements such as $\mathrm{Na}$ and $\mathrm{Ca}$. Zhang and Wagatsuma (20) found enhancement effects at most of the atomic lines tested and suppression effects at all of the ionic lines in the presence of $\mathrm{Na}$ and $\mathrm{Ca}$ with very high background. Naturally, in an emission spectroscopy technique, the detection limits of different elements would suffer from high background in geological and environmental matrices. The major advantage of MP-AES is its high sensitivity compared to the FAAS technique. The LOD is usually defined as the analyte concentration that produces an analytical signal equivalent

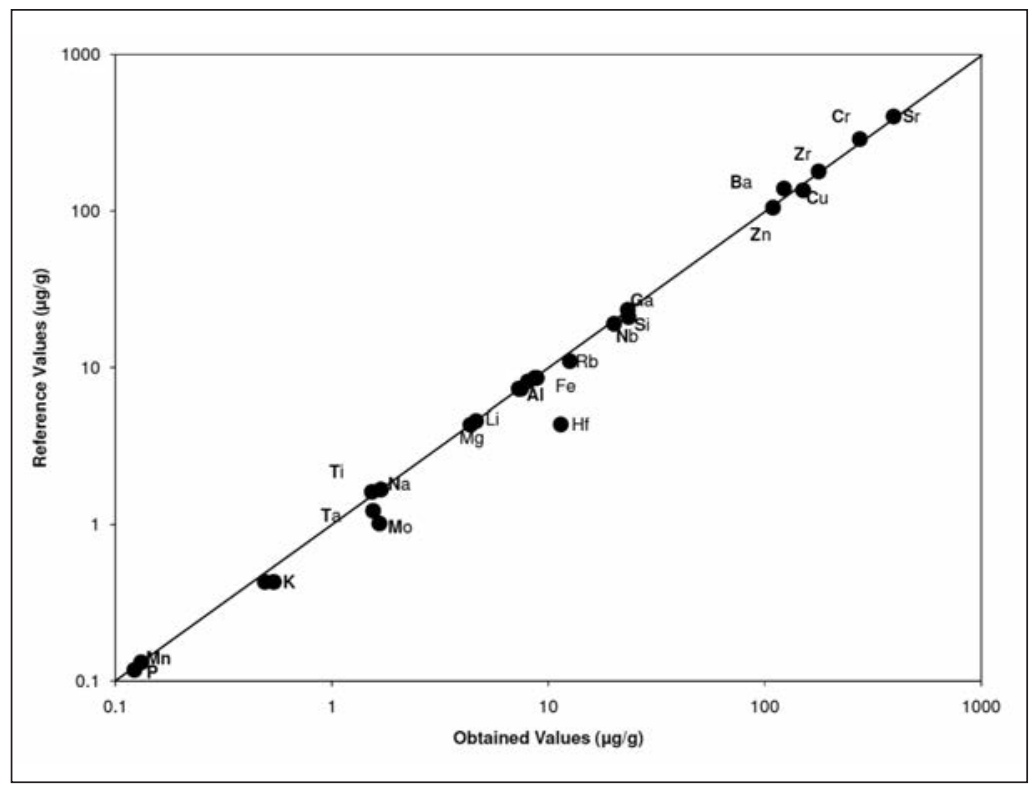

Fig. 6. Agreement between certified values $(\mu \mathrm{g} / \mathrm{g})$ and the values obtained in this study by MP-AES for various major, minor and some trace elements in international geochemical reference material, BHVO-1.

TABLE VI

Concentrations of Different Elements in Tap Water from the Mulgrave Area, Victoria, Australia, by MP-AES, in Comparison With Permissible Limits Set by WHO

\begin{tabular}{cccc}
\hline \multirow{2}{*}{$\begin{array}{c}\text { Ele- } \\
\text { ments }\end{array}$} & $\begin{array}{c}\text { Wavelength } \\
(\mathrm{nm})\end{array}$ & \multicolumn{2}{c}{$\begin{array}{c}\text { Concentration } \\
\text { MP-AES Study } \\
(\mu \mathrm{g} / \mathrm{mL})\end{array}$} \\
& & $(\mu \mathrm{g} / \mathrm{mL})$ \\
\hline $\mathrm{Ca}$ & 393.366 & 2.68 & 75 \\
$\mathrm{Zn}$ & 213.857 & 0.01 & 5.0 \\
$\mathrm{Fe}$ & 259.940 & 0.1 & 0.1 \\
$\mathrm{Mg}$ & 285.213 & 1.17 & 50 \\
$\mathrm{Co}$ & 340.512 & 0.01 & - \\
$\mathrm{Ni}$ & 352.454 & $\mathrm{BDL}$ & - \\
$\mathrm{Al}$ & 396.152 & 0.09 & - \\
$\mathrm{Mn}$ & 403.076 & 0.003 & 0.05 \\
$\mathrm{Ba}$ & 455.403 & 0.01 & - \\
$\mathrm{Na}$ & 589.592 & 3.72 & - \\
$\mathrm{K}$ & 766.491 & 0.62 & - \\
\hline
\end{tabular}

$\mathrm{BDL}=$ below detection limit.

$\mathrm{n}=6$, Precision $\leq 6 \%$ RSD.

Synthetic multi-element solution containing $\mathrm{Ca}, \mathrm{Mg}, \mathrm{Na} \& \mathrm{~K}$ (at $12.5 \mathrm{ng} / \mathrm{ml}$ ), Zn, Co, Ni \& $\mathrm{Mn}$ (at $1.25 \mathrm{ng} / \mathrm{ml}$ ), $\mathrm{Al} \& \mathrm{Ba}$ (at $5 \mathrm{ng} / \mathrm{ml}$ ) and $\mathrm{Fe}$ (at $2.5 \mathrm{ng} / \mathrm{ml}$ ) was used for calibration. 


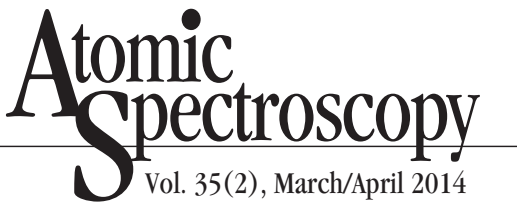

to three times the standard deviation observed for 16 measurements of a blank solution (24). The LOD, therefore, is determined by the sensitivity of the measurement and the noise level, or stability, of the MPAES instrument. Detection limits calculated for some elements are presented in Table VII in comparison with several other established analytical techniques. The detection limits obtained for MP-AES are much better than those reported for FAAS for several elements (25). The detection limits for all trace elements were found to be in the range of 0.1 to $33 \mathrm{ng} / \mathrm{mL}$ and are very closely approaching those of ICP-AES for several elements. MP-

AES is no match to ICP-MS in terms of detection limits (Table VII), however, in terms of maintenance cost and for the determination of a set of geochemically significant elements, it compares favorably. These studies indicate that the MPAES technique offers the required sensitivity together with a relatively higher resolution for a comprehensive analysis of geological materials.

\section{Accuracy and Precision}

Overall, precisions better than $\pm 6 \%$ RSDs were obtained for most determinations with comparable accuracy for all of the results obtained in this study (Tables III VI). However, precision was highly dependent on the absolute concentration in the material. Determinations made close to the MP-AES detection limit gave the poorest precision, as in the case of some trace elements, for example, Mo and $\mathrm{U}$, where the precisions were around 5-6\% RSD. More consistent results were obtained for elements at relatively higher concentration levels (all major and minor elements) with many yielding RSDs better than $\pm 3 \%$.
TABLE VII

Detection Limits for Different Elements by MP-AES in Comparison With Other Popular Analytical Techniques (FAAS, ICP-AES, and ICP-MS)

\begin{tabular}{|c|c|c|c|c|}
\hline \multirow[t]{2}{*}{ Elements } & \multicolumn{4}{|c|}{ Detection Limits (ng/mL) } \\
\hline & FAAS & MP-AES & ICP-AES & ICP-MS \\
\hline$P$ & 50,000 & 33 & 30 & 0.1 \\
\hline $\mathrm{Zn}$ & 1 & 2.8 & 1 & 0.04 \\
\hline $\mathrm{Au}$ & 6 & 1.8 & 20 & 0.005 \\
\hline $\mathrm{Ag}$ & 1 & 0.5 & 1 & 0.005 \\
\hline $\mathrm{Pt}$ & 40 & 4.5 & - & 0.005 \\
\hline Pd & - & 3.8 & - & 0.01 \\
\hline $\mathrm{Cd}$ & 0.5 & 1.4 & 1 & 0.005 \\
\hline $\mathrm{Be}$ & 2 & 0.1 & 0.1 & 0.012 \\
\hline $\mathrm{Al}$ & 30 & 0.6 & 3 & 0.01 \\
\hline B & 1000 & 1.3 & 1 & 0.012 \\
\hline $\mathrm{Mn}$ & 1 & 0.25 & 0.4 & 0.005 \\
\hline $\mathrm{Ta}$ & - & - & - & 0.0003 \\
\hline $\mathrm{Mg}$ & 0.1 & 0.12 & 0.1 & 0.020 \\
\hline $\mathrm{Bi}$ & 20 & 24.4 & - & - \\
\hline $\mathrm{Ti}$ & 50 & 7.9 & 0.5 & 0.004 \\
\hline $\mathrm{Nb}$ & - & - & - & 0.001 \\
\hline $\mathrm{Cu}$ & 1 & 0.6 & 1 & 0.005 \\
\hline Hf & - & - & - & 0.001 \\
\hline $\mathrm{Zr}$ & - & 10 & - & 0.007 \\
\hline $\mathrm{Ni}$ & 4 & 1.3 & & 0.01 \\
\hline Sc & - & - & 5 & 0.009 \\
\hline $\mathrm{Y}$ & - & 0.4 & - & 0.003 \\
\hline Mo & 30 & 1.5 & 3 & 0.08 \\
\hline $\mathrm{Fe}$ & 5 & 1.6 & 2 & 0.500 \\
\hline $\mathrm{Pb}$ & 10 & 2.1 & 10 & 0.0012 \\
\hline $\mathrm{Sr}$ & - & 0.1 & 0.06 & 0.001 \\
\hline $\mathrm{Ga}$ & - & - & - & 0.002 \\
\hline $\mathrm{Cr}$ & 2 & 0.4 & 2 & 0.005 \\
\hline $\mathrm{Ca}$ & 1 & 0.05 & 0.02 & 0.4 \\
\hline $\mathrm{Na}$ & 0.2 & 0.12 & 3 & 0.05 \\
\hline $\mathrm{Ba}$ & - & 0.2 & 0.1 & 0.01 \\
\hline $\mathrm{Li}$ & 0.5 & 0.01 & 0.3 & 0.01 \\
\hline $\mathrm{K}$ & 1 & 0.65 & 20 & 0.5 \\
\hline
\end{tabular}

ICP-MS detection limits (27).

ICP-AES detection limits (28).

F-AAS detection limits (25).

MP-AES detection limits by this study. 


\section{CONCLUSION}

The results obtained in this study clearly indicate that MP-AES (microwave plasma atomic emission spectrometry) is a suitable atomic emission spectrometry technique for the accurate determination of major, minor, and selected trace elements required in geochemical studies. This study also proves that by utilizing matrix matched calibration, potential sample matrix effects can be mini-mized in MPAES studies. So far, expensive analytical techniques such as XRF, ICP-AES, and ICP-MS are being used to generate precise geochemical data. This study carried out on several international geological reference materials proves that MP-AES is a more economical alternative analytical tool for the generation of precise data of major, minor, and some selected trace elements in geological samples.

The major advantages are that the microwave plasma, generated from nitrogen taken from direct air, does not involve handling any gas cylinders, is relatively less expensive, and can be operated with improved laboratory safety. This technique provides detection limits for several elements approaching that of an ICP-AES and is much superior to flame AAS. The linear dynamic detection range is of immense importance for any analytical technique because of the wide range of elements and concentrations to be analyzed in a single analysis. Better linear dynamic range achieved by MP-AES as compared to FAAS will enable the rapid determination of trace elements in different matrices and eliminate the need for time-consuming dilutions required for elements present at higher concentrations. Further investigations in the near future will include the accurate determination of other important trace elements such as As and Se, and especially the rare earth elements (REEs) in different kinds of geologi- cal and environmental materials such as rocks, soils, sediments, industrial effluents, and water.

\section{ACKNOWLEDGMENT}

We thank Dr. Mrinal K. Sen, Director, CSIR-National Geophysical Research Institute, Hyderabad, for providing permission to publish this work. P.R. thanks Dr. S. Rajan, Director, National Centre for Antarctic and Ocean Research, Goa, India. K.A. and C.T.K acknowledge the financial support from UGC and CSIR, New Delhi, respectively. V.B. would also like to thank CSIR, New Delhi, for financial support in the form of the Emeritus Scientist Scheme.

Received September 30, 2013.

\section{REFERENCES}

1. A. Walsh, Spectrochim. Acta 7, 108 (1955).

2. B.V. L'vov, Spectrochim. Acta Part B, 29, 149 (1984).

3. G. V. Hevesy, Nature 124, 841 (1929).

4. G. de Hevesy, H. Levi, and O. Rebbe, Biochem. J. 32, 2147 (1938).

5. S. Greenfield, I.L. Jones, and C.T. Berry, Analyst 89, 713 (1964).

6. R.S. Houk, V.A. Fassel, G.D. Flesch, H.J. Svec, A.L. Gray, and C.E. Taylor, Anal. Chem. 52, 2283 (1980).

7. N. Bradshaw, E.F.H. Hall, and N.E. Sanderson, J. Anal. At. Spectrom. 4, 801 (1989).

8. P. Myers, G. Li, P. Yang, and G.M. Hieftje, J. Am. Soc. Mass Spectrom. 5, 1008 (1994)

9. M.R. Hammer, Spectrochim. Acta Part B, 63, 456 (2008)

10. K. Jankowski, J. Anal. At. Spectrom. 14, 1419 (1999).

11. K. Jankowski, J. Yao, K. Kasiura, A. Jackowska, and A. Sieradzka, Spectrochimica Acta Part B, 60, 369 (2005).

12. A.M. Pless, B.W. Smith, M.A. Bolshov, and J.D. Winefordner,
Spectrochim. Acta Part B, 51, 55 (1996).

13. Q. Jin, C. Zhu, M.W. Border, and G.M. Hieftje, Spectrochim. Acta Part B, 46, 417 (1991).

14. Q. Jin, W. Yang, F. Liang, H. Zhang, A. Yu, H. Cao, J. Zhou, and B. Xu, J. Anal. At. Spectrom. 13, 377 (1998).

15. N.H. Bings, A. Bogaerts, and J.A.C. Broekaert, Anal. Chem. 82, 4653 (2010).

16. J. Zhang, R. Cheng, S. Tong, X. Gu, X. Quan, Y. Liu, Q. Jia and J. Jia, Talanta 30, 114 (2011).

17. V. Balaram, V. Dharmendra, P. Roy, C. Taylor, P. Kar, A.K. Raju, and A. Krishnaiah, Current Science 104, 1207 (2013).

18. V. Balaram, S.L. Ramesh, and K.V. Anjaiah, Fresenius J. Anal. Chem. 353, 176 (1995).

19. P. Roy, V. Balaram, A. Kumar, M. Satyanarayanan, and T.G. Rao, J. Geostand. Geoanal. Res. 31, 261 (2007).

20. W, Li, P. Simmons, D. Shrader, T.J. Herrman, and S.Y. Dai, Talanta 112, 43 (2013).

21. Z. Zhang and $\mathrm{K}$. Wagatsuma, Spectrochim. Acta Part B, 57, 1247 (2002).

22. K.S.V. Subramanyam, V. Balaram, U.V.B. Reddy, M. Satyanarayanan, P. Roy, and S.S. Sawant, MAPAN-J. Metrology Soc. India 28, 1 (2013).

23. D.R. Rao, B.L. Narayana, V. Balaram, Y. Shibue, K. Toyoda, A. Masuda, H. Honma, M. Kusakabe, H. Kagami, S. Iizumi, H. Sakai, Y. Kodama, and M. Kimura, Geochem. J. 25, 121 (1991)

24. G.L. Long and J.D. Winefordner, Anal. Chem. 55, 712A (1983).

25. B. Welz, Atomic Absorption Spectroscopy, pp. 506, 2nd Ed, VCH, Weinheim and Deerfield Beach, FL, USA (1985).

26. K. Govindaraju, Geostand. Newsl. 18, Special Issue 1 (1994).

27. V. Balaram and T.G. Rao, At. Spectrosc. 24, 206 (2003).

28. X. Hou and B.T. Jones, Encyclopedia of Analytical Chemistry, R.A. Meyers (Ed.), John Wiley \& Sons Ltd, pg. 9468 (2000). 